This is an Accepted Manuscript of an article published by Taylor \& Francis in Tourism Recreation Research on 21/06/2017, available online: http://www.tandfonline.com/10.1080/02508281.2017.1338817 


\section{Socially Sustainable Ethnic Tourism: A comparative study of two Hakka communities in China}

\section{INTRODUCTION}

Ethnic tourism has increasingly become a catalyst for economic and socio-cultural development nationally, regionally and locally, especially in many ethnic minority communities where options for development are limited (Ishii, 2012; Reimann, Lamp, \& Palang, 2011; L. Yang, 2013; L. Yang, Wall, \& Smith, 2008). The determination of control over business decisions and profit generation and distribution by ethnic tourism communities and government is often a contested space (Mowforth \& Munt, 2003). This contestation can produce "tensions" or "social conflict" related to the negative effects of ethnic tourism development on the host communities (Swain, 1989; Xie, 2001; J. Yang, Ryan, \& Zhang, 2013, 2014; L. Yang \& Wall, 2009). Notably, economic benefits derived from tourism have frequently caused tension between ethnic communities and outside entrepreneurs, local people and local governments (Crystal, 1989; Feng, 2008; Goering, 1990). When economic aspirations are overemphasised in tourism planning and development, the quality and sustainability of tourist destinations and quality of life for the host community may be compromised (Gossling, Ring, Dwyer, Andersson, \& Hall, 2016; Wagner, 2000). It is this notion of sustainability that is explored in this paper.

Sustainable tourism provides ongoing benefits for tourism destinations (Reimann et al., 2011; Zolfani, Maedeh Sedaghat, \& Zavadskas, 2015). Sustainable development and sustainable tourism involve three dimensions: economic, social and environmental (Swarbrooke, 1999; United Nations, 2005). Social sustainability in tourism is the ability of a host community to function harmoniously with the extra inputs introduced by its tourism development. This includes adapting its functions and relationships so that any disharmony created can be alleviated or mitigated (Mowforth \& Munt, 2003). 
While the Scale of Social Sustainability (SSS)-Host-Guest Conflict, Social Tolerance, and Social Acceptance-for tourism, provide assessments of social sustainability in destination settings (Zhang, Fan, Tse, \& King, 2016), further research is still needed to address what constitutes sustainability in the indigenous /ethnic tourism context (Whitford \& Ruhanen, 2016).

In China in ethnic regions tourism have been promoted by the government as part of a strategy for economic development and/or poverty alleviation. Ethnic tourism, typically community-based and in rural areas, has emerged as an important driving force for improving minority communities' living standards and bringing these communities into mainstream society (Ryan \& Gu, 2009; Zhou, 2014). Local distinctiveness and ethnic identity are promoted with the proviso that it is not a threat to the political or social order. The overarching aim of Chinese socialism is to integrate minorities with the majority Han society through incorporating the ethnic culture into the national political and economic framework (Oakes, 1992; Oakes, 1998; Sofield \& Li, 2007). The national socialist modernisation policy is juxtaposed with its cultural preservation policy, exacerbating conflicts between the government and some minority ethnicities (Sofield \& Li, 1998), and resulting in the loss of much traditional culture in Chinese folk villages (Xie, 2001). In consequence, reconciliation of the centripetal and centrifugal forces operating on ethnic tourism in China is a fundamental issue in debates about the sustainability of the country's ethnic tourism.

The local ethnic tourism environment and its cultural context play an important role in determining the scope of tourism development, and in addressing associated tensions (Y. Li, 2000; Y. Li \& Hinch, 1997). Just as the inherent values of ecotourism in a China are unique (Ye \& Xue, 2008) the conceptualisation of socially sustainable ethnic tourism and its operational components are culturally contextual, located firmly within a historical, social and political milieu (Ryan, Gu \& Zhang, 2009). Consequently, the meaning of 'sustainable tourism' in Chinese tourism development policy is not the same as in Western conceptualisations (Xu \& Sofield, 2013). Given the perception that Chinese government agencies are central to development of this emerging sector there is substantial theoretical and empirical justification for examining social sustainability 
and ethnic tourism.

This research sought to identify the main components of socially sustainable ethnic tourism from the host community's perspective. A case study of ethnic Hakka tourism in two southern Chinese villages, Nanyuan and Sujiawei Hakka communities in Heyuan, Guangdong Province, China (Figure 1) provided the basis to investigate how the role of government, commercial interest groups and the local community are incorporated into a social sustainability agenda (Huang, Ryan, \& Yang, 2013; L. Yang Wall \& Smith, 2008; Ying \& Zhou, 2007).

\section{INSERT FIGURE 1 HERE}

\section{LITERATURE REVIEW}

Ethnic tourism involves tourists seeking face-to-face contact with ethnic people and some form of direct experience with the host culture and environment (Harron \& Weiler, 1992; Wood, 1984). Ethnicity and culture in the host community are the principal attractant (Grünewald, 2003; V. Smith, 2001; Van den Berghe, 1994; L. Yang \& Wall, 2009) differentiating ethnic tourism from other sectors (Cornet, 2002). Ethnic tourism attaches primary importance to involvement of the local ethnic community in the cultural experience (Hitchcock, 1999; Jamison, 1999; van den Berghe, 1992; van den Berghe, 1994; van den Berghe \& Keyes, 1984; Wood, 1997). The numerous impacts of ethnic tourism on host communities are well documented (Butler \& Hinch, 2007; P. Li, Wang, \& Ryan, 2013; Ryan \& Aicken, 2005; Smith, 1989).

Ethnic tourism has been lauded for its culturally constructive contributions (Boissevain, 1996; Swain, 1989), conservation of natural and cultural resources (Jim, 2000), and its positive economic impacts (Chow, 2005; Pitchford, 1995). In China, the government has promoted ethnic tourism in many rural areas as a poverty alleviation measure to promote regional development. Benefits include improved local infrastructure, transport networks (P. Li, Wang \& Ryan, 2013), and the advocacy of ethnic tourism as a 
platform to achieve social harmony, social justice, social stability and social cohesion (Ishii, 2012; L. Yang, 2012; L. Yang, 2013). The sustainable development of ethnic regions present many challenges (Abrahams, 2015; Zhou, 2014), including cultural and environmental destruction (Greenwood, 1989; Selwyn, 1996) and adverse impacts on the culture, way of life and sense of identity of ethnic groups (Britton, 1982; Butler \& Hinch, 2007; Mowforth \& Munt, 1998; Oakes, 1998; Picard \& Wood, 1997; Ryan \& Aicken, 2005; Smith, 1989). The relationships between indigenous people and others, and within indigenous communities, are a key issue in ethnic tourism (Butler \& Hinch, 2007). These interest group interactions relate to local culture (ethnic identities, modernity, cultural commercialization and ethnic cultural representation), and community participation in tourism development (J. Li, 2004b; Sofield \& Li, 2007; Wood, 1984; J. Yang, Ryan \& Zhang, 2013, 2014; Ying \& Zhou, 2007).

The preservation of authenticity and cultural integrity are fundamental to sustainable ethnic tourism (An, 2006; Liu, 2002; Ma, 2000; Owen, Witt, \& Gammon, 1993; Shi \& Zhao, 2006; L. Yang \& Wall, 2009). Empirical research in Chinese ethnic regions has suggested authenticity is highly valued by tourists who seek different experiences, even in a staged context, and tourist satisfaction is enhanced by high service quality and authentic cultural displays (L. Yang, 2012). Research has revealed that government, tourism businesses, visitors and ethnic communities; the key stakeholders involved in authenticating cultural tourism, may hold conflicting views on cultural authenticity and commodification (Xie, 2001). In China, representation of minority culture has been found to be strongly influenced by the government and external managers who select the cultural products and direct the tourist's gaze (L. Yang, 2011). Dynamic power relationships operate between the different groups involved in Chinese ethnic tourism (J. Li, 2004a).

Government involvement in tourism may change an ethnic group's relationship with the government, and may even change relationships between individuals and institutions within the minority group (Henderson, 2003; Wood, 1984; Wood, 1993). In 
developing countries governments tend to play an active and sometimes a dominant, role in facilitating and promoting tourism development and providing a suitable socio-political and legal environment in which diverse stakeholders are involved and private initiatives can occur (Akama, 1997; Hughes, 1994). The degree of government intervention in tourism planning and development in China is a case in point (Hall, 2007; Huang, Ryan \& Yang, 2013; L.Yang, Wall \& Smith, 2008; Ying \& Zhou, 2007). Local governments assume responsibility for facilitating the sustainable tourism agenda but it is unclear how this is best accomplished (Ruhanen, 2013; C. Wang \& Xu, 2014) or the rights of ethnic groups in its development. This paper explores these interest group relationships through an investigation of socially sustainable ethnic tourism in Heyuan, Guangdong, China.

Local communities have emerged as new forces in developing ethnic tourism, with some ethnic villages independently organising tourism enterprises and creating tourism precincts. Locals manage sanitation and safety in their villages, and some villages specialise in providing tourists with distinctive ethnic food, ethnic performances and displays of authentic ethnic songs and dances. A community-led approach to ethnic tourism development is being practised in some regional areas, albeit under a centralised government system. The reconciliation between centralised state power and local autonomy are two key driving forces shaping ethnic tourism in China. This research explored the ways in which two regional villages developed and operated ethnic tourism and implications on socially sustainable ethnic tourism in China.

\section{METHOD}

A primarily qualitative approach was chosen for researching the nature of socially sustainable ethnic tourism in a Chinese context as explanations of social phenomena and context are better addressed through qualitative enquiry. The qualitative enquiry was supplemented with a discussion with selected households about residents' perception of ethnic tourism development in their local area. Given that ethnic tourism destinations have a 'geographical boundary' it was deemed that a case study approach 
was an ideal method by which to explore sustainable ethnic tourism.

\section{Case Study Site Selection}

The research was conducted in Guangdong Province, located at the south-east of the Chinese mainland, bordering the Hong Kong and Macao Special Administrative Regions. Among China's 56 government-recognised ethnic groups, there are 53 with a presence in Guangdong (People's Government of Guangdong Province, 2012). Over 30 million people from Guangdong have emigrated overseas representing two-thirds of the Chinese living outside China across 160 countries and regions. Some 103,000 returned overseas Chinese and over 20,000,000 relatives of overseas Chinese are from Guangdong. Many overseas ethnic Chinese and their Hong Kong and Macao expatriates in organised international Hakka visitor groups travel to the Chinese mainland for ancestral exploration or participation in ancestor worship (Luo, 2006). In 2012, inbound visitor arrivals reached 107.9 million person trips in Guangdong, with 100.3 million person trips by patriots from Hong Kong, Macao and Taiwan (Guangdong Statistical Bureau \& Guangdong Survey Team of National Statistical Bureau, 2013). In 2016, tourism revenue totalled US\$166 billion, and foreign exchange earnings from tourism reached US\$19 billion in Guangdong region (The southern news, 2017).

In 2014, arrivals of overnight visitors and the-same-day visitors reached 696,900 and $4,866,300$ person trips respectively, with 18,700 person trips of international tourists (foreigners, Hong Kong, Macau and Taiwan compatriots) in Dongyuan county. There were 76 tourist hotels ( 1 two-star hotel and 1 three-star hotel) and 3 domestic travel agencies (Heyuan Stastics Information Network, 2016b). By 2015, tourist arrivals in Dongyuan County, had reached 6.45 million person trips and gross tourism revenue was US\$660 million.

Heyuan is a prefecture-level city of Guangdong province and is located in the 
north-east of Guangdong Province. It is the residential centre for Hakka people in the Dongjiang River basin with 97 pure Hakka townships (Zqhnet, 2009), and is composed of five counties (Dongyuan, Longchuan, Zijin, Lianping, and Heping) and one district (Yuancheng), covering a total area of 15.8 thousand square kilometres with a population of 3.4 million. The Hakka dialect is mainly used in this area, which is not easily understood by Mandarin speakers (Zheng \& Huang, 2010). Cultural tourism has become a key part of Heyuan's tourism development. "Hakka ancient town" was set up as a new tourism site. Since the late-1990s, tourism in Heyuan has increasingly risen. In 2015, tourist arrivals in Heyuan amounted to 25.4 million person trips, of which, international tourists arrivals were 76,200 and overnight tourist arrivals totalled $11,095,900$ person trips, with $29.6 \%$ and $16.8 \%$ growth over the previous year respectively. Gross tourism revenue was US\$ 33.9 m. By 2015, 42 travel agencies, 19 star-rated hotels (one five-star and two four-star hotels), ten A-level scenic spots and six 4A- level were found in Heyuan (Heyuan Statistics Information Network, 2016a).

Nanyuan and Sujiawei were selected as the two Hakka community case study sites as they have similar socio-economic and cultural backgrounds under the same public administration system, Dongyuan County, Heyuan of Guangdong Province, China. Interviews, household discussions and secondary data sources were conducted in each Hakka community to provide a multi-perspective analysis with a holistic description of a case from a variety of sources (Tellis, 1997).

Nanyuan and Sujiawei are marketed as two representative ethnic Hakka tourism destinations for both domestic and international tourists in Dongyuan County of Heyuan. Located only $11 \mathrm{~km}$ apart, Nanyuan and Sujiawei are typical representations of the Hakka Culture- a specific Chinese ethnic culture with guest immigrants integrating their cultural components into the local/ indigenous culture in China or host country outside of China (Dongyuan County People's Government, 2015; Luo, 2006). These two Hakka communities share some similarities in aspects of their tourism settings as shown in Table 1. Hakka historic buildings, a Hakka cultural exhibition and a 
"Countryside Tour" are the main features, with inclusion in tourism routes and tour packages as the main promotional vehicle for their tourism products. For instance, at present, most tourists to Nanyuan come from the Pearl River Delta region and Hong Kong, with fewer tourists from Macao. Since 2008, most domestic and international tourists who travelled there were in tour groups, and $70 \%$ of these groups were organised by outside tourism travel agencies. Outside travel agencies organise groups of tourists and entrust Heyuan travel agencies to arrange visits and sightseeing and tourists' food and accommodation.

\section{Semi Structured Interviews}

Purposive sampling was used to establish a good fit between research questions and sampling (Bryman, 2008). In China, seeking information via a face-to-face approach is the main way to show respect to the participant. In the first instance, face-to-face in-depth interviews were held with regional and local government officials, tourism enterprise managers and leaders of local communities to explore their perceptions of a sustainable approach to ethnic tourism. For Nanyuan, 11 in-depth interviews were conducted with regional and local government officials, tourism enterprise managers and members of villagers' committee over a two-year period (2012-2014). In Sujiawei, ten in-depth interviews were conducted with regional and local government officials and tourism enterprise managers during the same period. Interviews were in Mandarin in the interviewees' workplace, or a location of their choice, varying from 15 minutes to 90 minutes in duration. With the participants' permission, interviews were recorded. The interviewees were provided with an opportunity to reflect on their experiences in tourism management and were encouraged to share their insights into tourism development.

\section{Household study}

As part of inclusive approaches ethnic tourism research practice (Yang \& Wall, 2014), the study sought to go beyond government, business operators and decision-makers the views of and we engaged with those living in the ethnic tourism 
precincts. The household study was designed to explore local people's perceptions of the benefits and challenges of community-based tourism, community participation in tourism, factors influencing community participation and community participation preferences and strategies to improve ethnic tourism development. The questions were both open-ended and structured with response options in consideration of the respondents' cultural and literacy levels. Before formal data collection commenced, a pilot survey was conducted with Hakka people to pre-test the questions. Following the pilot testing, some minor wording changes were made.

In Sujiawei, the smaller community, all households were approached to be involved. In Sujiawei, 22 households agreed to participate in the survey and 12 households refused to participate. In Nanyuan, random sampling was used in an attempt to gain responses from approximately $20 \%$ of households. In the Nanyuan community, there are approximately 500 households of Hakka Chinese, and of these 103 households agreed to participate and 42 households declined.

The interviewer approached participants in their homes. Obtaining responses from less-educated locals and from older adults was challenging and required patience by the researcher and the interpreter. Some 125 households agreed to discuss ethnic tourism with the interviewer. Analysis of the responses was restricted to descriptive statistics and is reported as part of the narrative in the findings.

\section{Secondary data sources}

Government documents on tourism planning and tourism development were collected and examined to provide a better understanding of how governments at all levels perceived and facilitated community participation in tourism and their respective perceptions of sustainable tourism. This included official documentation on the two cases, together with local newspapers and internet resources developed for tourism promotion, and photographs and field notes and diaries. The analyses of these secondary data sources are presented as part of the narrative in the findings. 


\section{FINDINGS}

This section begins with an overview analysis of the two case study sites and then reports on the four themes derived from the analysis, namely: social sustainability; community participation; the role of local government; and sustainable interest group relationships. Table 2 shows the themes and sub-themes.

\section{INSERT TABLE 2 HERE}

\section{Ethnic tourism in Nanyuan and Sujiawei}

Nanyuan is a community owned and managed ethnic tourism precinct. Due in part to the lack of government financial support and as a consequence, a relatively modest level of tourism visitation it struggles financially. The lack of development capital limits Nanyuan's offerings as an ethnic tourism attraction. It was not until 2012 that overall tourism planning of the Nanyuan tourist zone was formalised, even though Nanyuan initiated its tourism early in 2003. Environmentally, the historic precinct is subject to encroachment by the modern town compromising its authenticity as an historic ethnic tourism attraction. Apart from some restored buildings, Nanyuan's historic precinct offers few cultural attractions and activities. A new "farming adventure" attraction was the one "cultural engagement" activity for visitors aside from sightseeing and few food/accommodation.

By 2012, tourism business to Nanyuan had stagnated due to lack of government support, and a lack of human and financial resources. In 2014, tourist arrivals in Nanyuan were 91,455 person trips, about one sixth of that in Sujiawei (514,818 person trips) (Heyuan Stastics Information Network, 2016b). A follow-up interview indicated that the Nanyuan Tourism Enterprise had actually suffered a loss of income despite a small increase in tourist numbers (tourism enterprise manager, personal communication, 
November 19, 2014). Although Nanyuan's Tourism enterprise generated limited income and financial benefits for the local Hakka community, as a community owned and managed tourism enterprise the tourism precinct commands considerable community support. The lack of profit limits investment in tourism development. The local government lacks funds to conserve the architectural authenticity on which tourism is based. This in turn threatens the authenticity of the heritage environment that tourists are exposed to and limits expanding tourism offerings (e.g. accommodation) that could provide a much higher yield and therefore profit.

Conversely, Sujiawei was a commercially successful joint venture between the Heyuan local government and a private entrepreneur. Sujiawei benefits from being a small village located in an attractive rural setting. The local government initiated the Sujiawei enterprise, and later transferred part of its business ownership to the enterprise. As a joint-stock enterprise, with a high level of local government control the Sujiawei ethnic tourism development has attracted considerable government and private sector funding support for infrastructure development and marketing. As one provincial government official explained, having strong government involvement in ethnic tourism enterprises attracts considerable investor support.

Government funding support is the way in which government can lead the tourism development. Once government participates in tourism investment, other investors will invest with increased confidence (provincial government official, personal communication).

Sujiawei has been professionally managed and is classified by the provincial government as an authentic Hakka cultural heritage site. It enjoys a high level of visitation, tourists have many points of visual interest and there are several interesting cultural activities to experience as well as food and handicrafts to purchase. The local Hakka have received tangible employment, business and broader economic benefits from the ethnic tourism enterprise. However, the Sujiawei enterprise gives locals little opportunity to exercise any managerial or operational influence over the tourism 
precinct.

The characteristics of social sustainability in ethnic tourism in Nanyuan and Sujiawei are outlined in Table 3.

Insert Table 3 here

\section{Theme 1: Social Sustainability}

The host community's control over local tourism development and its interest in the distribution of the benefits from tourism must be considered to meet basic needs and foster a good quality of life for all members at the individual, group and community level (Swarbrooke, 1999). Socially sustainable ethnic tourism is measured by the degree to which a community is empowered to control and direct ethnic tourism enterprises.

In Nanyuan, the local Hakka community owned and managed the tourism enterprise and had a high degree of control over decision making. The villagers' committee, an autonomous organisation, was set up by grassroots election and is a legal entity, representing local people and protects their lawful rights and interests. A villagers' group is subordinate to and led by the villagers' committee. In return for his or her resources and personal commitment to local ethnic tourism development, each person in Nanyuan can share in a year-end bonus from tourism development on an individual basis when and if there are financial returns from tourism. The local community's involvement in Nanyuan Enterprise is an example: 'Local people elect and replace their village committee every three years ... Each big house comprises a few village groups and the leader of each village group recommends a person to the village committee to work in businesses' (Manager of a locally owned tourism enterprise).

In Sujiawei, an entrepreneur and the local government own the tourism enterprise. The local Hakka community has little input into policy and management decisions. 
On this measure of social sustainability, Sujiawei ranks poorly. All small businesses in Sujiawei were controlled and regulated by the external tourism enterprise. The high level of economic benefit through external investment came at the expense of a lack of control and input by the local community. This influenced local people's access to some tourism services/benefits, and only a small proportion of the benefits from tourism was distributed to the local community. Some local people complained: 'Sujiawei's tourism enterprise rarely considered local people's interests. For instance, the public toilets in the tourist zone are usually closed at night. This has brought inconvenience to us in our daily life' (a local resident, an informal conversation).

Tangible financial benefits from ethnic tourism enterprises occurred in both Nanyuan and Sujiawei. Employment and business opportunities were created and tourist visitation added to the overall income of both villages, together with improved village infrastructure. However, local residents in Sujiawei gained far greater economic benefits from external government/private sector operated ethnic tourism venture than Nanyuan did from its local community managed tourism enterprise. Half of the household respondents in Sujiawei stated that their family income had increased in contrast to a few respondents (15\%) in Nanyuan. This was largely because Sujiawei was more professionally managed and subject to far greater government support than Nanyuan.

\section{Theme 2: Community participation and perceptions}

Within similar tourism settings, Nanyuan has adopted a community-led ethnic tourism development approach, while Sujiawei is an ethnic tourism development dominated by external organisations. Consequently, the interrelationships of interest groups involved in ethnic tourism and outcomes of their tourism development differed widely in Nanyuan and Sujiawei. For instance, as a consequence, the two villages face different challenges. Conservation of natural and cultural environment, upon which the sustainability of ethnic tourism depends, is challenging Nanyuan; while integration with local people is a primary issue confronting Sujiawei tourism 
enterprise. A local newspaper reported that in 2011, without giving any reason, the Sujiawei tourism business stopped paying locals rent, an agreed price which ranged from tens to hundreds of RMB. The leader of the Sujiawei council Jizhong Su said that the locals did not know the reason for this and even he, as an associate president of the council, had no idea of why the decision was made. A local complained: 'there was originally an area where local peoples could sell their local special products to tourists. The Sujiawei enterprise ended this arrangement without involving locals in the decision-making.

Local perceptions and acceptance for tourism are essential indicators for social sustainability in destination settings (Zhang, Fan, Tse \& King, 2016). In Nanyuan, a variety of internal community tensions were observed in different stages of Nanyuan ethnic tourism development. However, most local people indicated that they support Nanyuan's tourism development, with $54 \%$ of household respondents in Nanyuan expressing satisfaction with the existing tourism enterprise, and only $15 \%$ noted dissatisfaction. The significantly high level of satisfaction with Nanyuan's tourism enterprise results from the sense of ownership in Nanyuan's ethnic tourism development. A “Farming Fun Business" (in Chinese: 农家乐) was started to help local Hakka people do farm work. Students from Hong Kong travel to Nanyuan old village during the farming season and assist local Hakka people to harvest paddy rice and peanuts, and grow vegetables. They also go to the farmers' house to eat local Hakka food and experience local peasants' life. The development of this initiative was firmly based in community participation:

Before starting this program, the tourism enterprise approached local farm households to participate in this tourism business. If the farm owner wished, the enterprise would send tourists to them and train the farmer on how to take steps in providing appropriate levels of sanitation and safety. Then an agreement was signed between Nanyuan Enterprise and the local farm household (Manager of a locally owned tourism enterprise).

Theme 3: The role of local government 
In Sujiawei, direct conflict between the external enterprise and residents was evident, together with indirect conflict between the government and the local community. A sizeable group of household respondents (32\%) were dissatisfied with the Sujiawei enterprise with only $23 \%$ expressing satisfaction. Clearly the operation of external management of the tourism enterprise vexed some members of the Sujiawei community. Dissatisfaction centred on a perceived lack of benefit distribution from tourism, leaving a legacy of distrust between the people and government and between local people and the tourism businesses. In China, social harmony is incorporated in the national and local tourism policy, but benefit sharing issues in Sujiawei ethnic tourism are challenging both sustainability of Sujiawei tourism business and harmony between the local ethnic community and the external organisations.

Local government's promotion of industrial development in or near the Nanyuan local community contributes to peoples' livelihood but uses the old village's natural environment. Conservation problems undermined the cultural integrity and tourism industry of Nanyuan. Local community members were not motivated to conserve authentic building standards due to lack of financial resources and the lack of local tourism-related regulations applying to conservation in the tourism destination. Preservation of authenticity and cultural integrity are fundamental to sustainable ethnic tourism (Xie \& Wall, 2002; L. Yang \& Wall, 2009). The original Hakka culture and its environment constituted core elements of authenticity. Environmental conservation was critical for maintaining a cultural and historic spirit. The majority of household respondents indicated that historic buildings most represented their Hakka culture ( $82 \%$ in Nanyuan and $78 \%$ in Sujiawei). In Nanyuan, degradation of cultural and historical authenticity encroached on the community-controlled tourism precinct. Due partially to lack of long-range tourism planning the lack of rigorous tourism management, inadequate cultural preservation (Heyuan Stastics Information Network, 2016a), and the cultural destruction of artefacts and buildings in Nanyuan the attraction and authenticity of the ethnic tourism experience is compromised. 
Conversely, the external management group of Sujiawei emphasised advancing the quality and authenticity of the tourism precinct. As local government was a key owner it imposed architectural and environmental authenticity on its disempowered residents. The Sujiawei tourism enterprise's commitment to authenticity, backed by generous local government financial support, was recognised in April 2013 when Sujiawei was awarded an AAAA tourism rating by the provincial government. Sujiawei was actively promoted as an authentic Hakka tourism destination by both government tourism authorities and the private sector tourism industry. However, in Sujiawei, the tourism enterprise just maintained those tourism resources which could bring economic benefits to them and ignored others. The external tourism enterprise managers have realised that the increasing modern elements, such as air conditioning and solar heating installations on the roofs or outside walls of local people's houses, compromise the original appearance of the Hakka village, but they have been unable to persuade local people to cooperate with them to maintain an authentic tourism image and culture. Lack of government building regulations in the tourism area and lack of government coordination made it difficult for the tourism enterprise to alleviate the tension between modernisation and cultural conservation.

Our analysis showed that local government policy in the real estate industry influenced the business operation approach, and thus limited the diversity of tourism products and services and the extent to which tourists could experience authentic ethnic culture in ethnic tourist destinations. In both Nanyuan and Sujiawei cases, the "benefit" tourists received from their direct engagement in tourism was mainly restricted to sightseeing tours. Tourists usually had a brief stopover there. Few utilised accommodation available in the tourism area, or appreciated the spirit of this whole tourism area. There was little evidence of follow up visitation. Under such circumstances, tourists experienced a hurried glance at the local culture and had minimal experience of ethnic people's daily lives, or the ethnic culture. It is clear that the single tourism business operation hindered tourists from having a comprehensive 
cultural experience in tourism destinations. Authenticity not only requires maintenance of original culture, but also a dynamic living artistic cultural development. This cultural development is based on some original culture and integrates both modern and creative elements. The vast majority of tourists do not demand "total authenticity", and thus their criteria for judgments of authenticity will often focus on selected traits of the cultural product, disregarding others (Cohen, 1988).

\section{Theme 4: Interest Group Relationships}

This study also identified sustainable interest group relationships in ethnic tourism development as critical for the provision of socially sustainable ethnic tourism in the host communities we studied. In these relationships, the local community is the owner of the tourism development and businesses. Governments at all levels are the outside helpers of the local community's tourism development, providing support for the local tourism development. External businesses are invited to be in charge of tourism investment, operations and construction.

In Nanyuan, the local government expects to strengthen its role and responsibility in local tourism policymaking through planning of the tourist attraction, enacting tourist attraction-related legislations and regulations, coordination and policy support for community participation in tourism for the provision of sustainable tourism:

It is necessary for the local government to be responsible for tourism planning of tourist attractions. The government must protect the whole environment and implement overall tourism planning, and introduce strong businessmen and guide local peoples to operate tourism (Government-owned tourism business manager).

However, a provincial government official acknowledged that corruption issues challenged this government involvement: 
It is necessary for government to support and coordinate tourism planning. Any change in tourism planning must be made based on the original procedures through which tourism planning was initially formulated. This, in most cases, involves major elements of tourism law or tourism control regulations. It is very difficult to do this. Corruption or bureaucracy issues have emerged and exist in market economy development. It is therefore difficult to deal with this problem (Provincial government official).

Business ownership was found to be a critical component in structuring the interest group relationships. Ethnic tourism businesses' achievements and ownership structures determine the degree to which the local government gains economic benefits from local tourism operations. A tourism business manager said:

The real leading role is not the enterprise, it is the local people. It is not enough to operate this rural tourism business only as an enterprise. There are a lot of things the enterprise cannot deal with on its own. The effect of advertising is also very limited if there only business employees do the advertisements. All the people of the tourism area must be involved in this business. This is what I want to emphasise (Manager of a privately owned tourism business).

A manager explained: 'You cannot successfully operate and manage this tourism area if the local Hakka people think they don't need it' (Privately-operated tourism manager).

Policy priorities for sustainable tourism development can influence local government perceptions and implementation of community participation in tourism. Local community participation in tourism policy/planning is not high on the national, regional or local government agendas. Emphasis is placed on providing local people with the opportunity to receive economic benefits from tourism and this economic consideration is perceived as the criterion for successful tourism development. From a policy perspective, sustainable ethnic tourism in China involves achieving a balance between community empowerment and community benefit. 


\section{Discussion}

The comparative examination of social sustainability in ethnic tourism in Nanyuan and Sujiawei indicated that integrating the interests of the groups involved in tourism was the key to reducing social disharmony in the host communities. In both cases, the three main interest groups were: government (political organisation), tourism enterprise (commercial organisation) and the local community (socio-cultural organisation). In Sujiawei, the involvement and commitment of local government as a key owner and stakeholder of the tourism enterprise facilitated a viable business operation and through the enforcement of government regulations, authenticity was preserved. Despite substantial economic and environmental benefits in Sujiawei resulting from the ethnic tourism enterprise, a sense of alienation existed within the community towards the tourism enterprise.

The community supported the economic benefits of the tourism enterprise but expressed dissatisfaction over the lack of community empowerment. They questioned the extent of equitable distribution of benefits to the community. Although many were employed in associated businesses, local people felt excluded from direct ownership and decision-making. In Sujiawei external entrepreneurs cooperated with government and assumed increased control. Tourism developments with an absolute predominance of external capital, while common in China, are not socially sustainable in rural China (Ying \& Zhou, 2007). The balancing of community involvement and the benefits of external capital remain fundamental to sustainability in ethnic tourism.

\section{The Significance of Community Empowerment in a Chinese Context}

Despite its relatively modest business results, Nanyuan's communal owned and managed tourism enterprise, generated a high level of social solidarity and support from the local community. Community control is essential to socially sustainable ethnic tourism and a lack of empowerment can generate tensions between the ethnic community and external owners of ethnic tourism enterprises. Community involvement may at least increase the local community's tolerance of tourism and 
tourist behaviour (Swarbrooke, 1999). While the Nanyuan community was generally positive about community ownership of the ethnic tourism enterprise, some advocated increased government financial support for ethnic tourism. Meanwhile, there was also a divergence of views between the tourism enterprise and the villagers' committee over the optimum use of resources, and tension between government and the local community over control. The insider approach to tourism development may be just as problematic as anything else (Taylor, 1995). In the social process of community participation, local people seek to achieve full control of a program while the power holders are liable to manifest paternalism and resistance to the power redistribution implied in community participation (Arnstein, 1971).

\section{The Significance of Government in Socially Sustainable Ethnic Tourism in China}

The Western archetype of sustainable ethnic and indigenous tourism asserts that the capacity of indigenous peoples to be involved in tourism operations on their own terms is essential for sustainable ethnic tourism (Colton \& Harris 2007). Yet, in the Chinese paradigm some communities may lack the requisite skills to effectively participate in or manage tourism enterprises (Bao \& Sun, 2007). In Nanyuan and Sujiawei there was a complex interplay in the two different forms of ethnic tourism governance and participation. Access to resources (human and/or financial) for tourism development was linked to the facilitation or restriction of community participation. Despite strong government control, there was little evidence of mandated community participation in tourism policy/planning, benefit sharing or cultural conservation.

Given the primacy of government control in China, it is not surprising that the overwhelming majority of household respondents surveyed indicated that the government is important in facilitating interest group interactions for building collaboration and partnerships across sectors involved in ethnic tourism. Government involvement in tourism may change an ethnic group's relationship with the national government and with other groups, and even change relationships between individuals 
and institutions within the minority group (Wood, 1984; Wood, 1993).

In the two cases, public sector policy and funding was identified as a key determinant of the practices of community participation and social sustainability in ethnic tourism development. Local government often assumes responsibility for facilitating the sustainable tourism agenda (Aronsson, 2000; Ruhanen, 2013). This study's findings indicate that stakeholders expect local government to carry out a fundamental role in tourism policy and governance to support cultural and environmental preservation in and near the tourist attractions. This involves enacting local tourism-related regulations and legislation for improvement of conservation, and providing financial support for cultural preservation. Yet, as already identified they need to have the financial resources to do this in an effective and timely manner (Tosun, 2000).

The factors identified in this study that constrain local government from playing a leading role in tourism planning include tensions over control between different government sectors. The process of tourism policy development and implementation in China is an inter-organisational process, and the public administrative arrangements of tourism management constrain policy implementation (D. Wang \& Ap, 2013). In the initial stages of tourism development, local government should ideally be involved in planning, regulation and coordination to control the orderly development of tourism. Otherwise, development may adversely affect the local community and diminish the attractiveness to tourists.

Authenticity underpins the ongoing sustainability of ethnic tourism. Without the host community's ethnic people, their cultural traditions and preserved heritage environment, there is no viable ethnic tourist activity (Smith, 1990). To meet tourists' expectations of authenticity, it is necessary to maintain the cultural, architectural and environmental atmosphere that is critical for maintaining cultural and historic authenticity. Strategies for the preservation of culture and authentic ethnic tourism contribute to the quality of ethnic tourism experiences. The Chinese government's 
modernity agenda can compromise ethnic tourism's premise that people's daily life includes traditional culture and arts, traditional food and life style. In both villages some local residents retained their traditional culture regardless of ethnic tourism. However, local community members struggled to keep their built heritage authentic due to their lack of human capital, financial resources coupled with the absence of local tourism-related regulations for conservation of tourist attractions. In addition, the local community's lack of awareness about the nuances of sustaining authenticity exacerbated the situation. Our findings suggest that it is not only a contested 'modernity' that challenges authenticity but a growing desire by individuals to use the economic benefits of ethnic tourism for their own individual rather than collective purposes.

The "visual gaze" (Urry, 1990, 2002) of tourism was perceived differently by stakeholders. For ethnic tourism precincts, the importance of preserving buildings was acknowledged. However, there was awareness that ethnic tourists sought more sophisticated tourism experiences that provided greater insight into the authenticity of the local culture through experiencing the daily lives of ethnic communities. Current trends in tourism development suggest that homestays and cultural interaction provide tourists authentic engagements with ethnic communities, and direct interaction that is mutually beneficial and this activity has a direct economic benefit for locals. This means that destination marketing should emphasise the emotional benefits associated with authentic tourism experiences through a combination of entertainment, excitement and education, rather than merely describing the diverse and individual attractions of the destination (Dwyer, Edwards, Mistilis, Roman, \& Scott, 2009; United Nations World Tourism Organization, 2002). These experiences require partnerships between ethnic tourism providers, tourism business owners, tourism wholesalers, and government coordinating bodies. To meet market demand for ethnic tourism products, ethnic communities need to actively participate in the decision-making and planning processes to determine those aspects of culture which constitute the foci of tourism experiences (Abascal, Fluker, \& Jiang, 2016). Such 
partnerships in ethnic tourism contribute directly to the ongoing social sustainability of ethnic tourism enterprises, the tourism supply chain and the valuing of the ethnic tourism sector.

Sustainable development is intended to improve the residents' quality of life by optimising local economic benefits, protecting the natural and built environment and providing a high-quality experience for visitors (Bramwell \& Lane, 1993; Park \& Yoon, 2009; Stabler, 1997). In this study socially sustainable ethnic tourism was conceptualised as a sustainable approach which ensures the cultural integrity, ongoing social, economic and environmental future of the ethnic community (Bramwell \& Lane, 1993; Harron \& Weiler, 1992; World Commission on Environment and Development, 1987; L. Yang, 2011). We found that sustainable interest group relationships are critical for the provision of socially sustainable ethnic tourism. Public sector policy plays a pivotal role in adjusting interest group relations to sustainable tourism, due to its role in funding, managing and regulating sustainable tourism through planning and legislation (Huang, Ryan \& Yang, 2013). Public sector policy could be further adapted to support for community participation in tourism policy/planning development, coordinating tourism-related resources, and legislation/ regulation for conservation and authenticity.

\section{CONCLUSION}

The Nanyuan and Sujiawei case studies provide insights into how sustainable ethnic tourism is constituted. Community participation and control was central to improving the quality of life for the host community, and ethnic tourism experiences for visitors. Previous research noted the critical position of Chinese government policy and support play in sustainable tourism. We add to this body of work by highlighting consequences and nuances of this involvement. Public sector policy is recognised as important for sustainable tourism, and greater attention should be paid to improving its effectiveness and its democratic character (Bramwell \& Lane, 2010). The majority of village residents interviewed felt public sector policy could be used to 
consistently ensure community participation in tourism policy/planning development, coordinating tourism-related resources, and legislation/ regulation for conservation and authenticity. Overarching legislation, policy and heritage conservation funding needs to be provided at the national and regional levels where significant heritage protection can contribute towards the preservation of authentic cultural artifacts and dynamic living ethnic communities (Hall 2007).

Social sustainability requires greater involvement of local communities in decision-making, management, business operations, community consultation and benefit distribution. In the Hakka villages investigated for this study, locals worked as employees, provided tourism resources, and operated small businesses. However, as most locals had lower levels of education, lacked associated human capital management skills, it was not surprising that few held managerial roles in ethnic tourism enterprises.

Traditional ethnic community would benefit from greater access to training and development in sustainable tourism operations. This enables a direct connection between ethnic tourism development, local employment and career development. Meaningful tourism education across all stakeholder groups at the local community level could facilitate enhanced understanding and greater awareness of cultural conservation and its contribution to a sustainable tourism agenda. Social sustainability should ensure that tourism operations prioritise improving the quality of life for the host community, and the quality of ethnic tourism experiences, incorporating conservation, authenticity and diversity of tourist experiences and hospitality.

The strategies for partnerships in ethnic tourism development signal the need for improved communication between government, enterprises and local communities, emphasising the centrality of building partnerships and improving community participation in promoting sustainable tourism. Overall, it is essential that government plays an active role to ensure tourism is developed sustainably in China. Ethnic 
tourism practices should address means to ensure recognition of the role of local communities in cultural preservation and authenticity. The preservation of heritage also aids ethnic tourism development.

Social sustainability requires enhanced involvement of local communities in decision-making, management, business operations, community consultation and benefit distribution. Community participation in tourism benefit allocation and decision-making should be complementary factors, and are successive phases of the community participation process (Ying \& Zhou, 2007). Furthering previous research, this case study's findings suggest that community participation may evolve from local involvement in tourism benefit sharing to involvement in decision-making and planning. Meaningful tourism training and education across the traditional ethnic community would improve the capacity of local people to become informed decision makers.

From a government perspective, there is a need to assist local communities in understanding the nature of their involvement and the roles that they can play in the process of shaping their local community. Tourism enterprises could work with local communities to reduce the reliance on outsourcing middle and senior management. They could train local middle management members, who could mentor other members of the traditional ethnic community. If staff recruitment drew from these groups, there would be a direct connection between ethnic tourism development, local employment and career development. Local mentoring would facilitate local community greater awareness of cultural conservation and its contribution to a sustainable tourism agenda in these tourism destinations, enhancing economic and social outcomes for the whole community. This study highlights the centrality of sustainable interest group relationships for socially sustainable ethnic tourism. Building on this knowledge, future research could beneficially explore mechanisms for improved communication and collaboration between government, tourism enterprises and local communities, in promoting sustainable tourism. 
This study and the location of the fieldwork, involved a number of delimiting factors including the locations chosen, environmental factors, and language interpretation issues. There are also 'Chinese cultural' considerations in terms of disclosure, as political considerations and traditional values could constitute barriers to objective knowledge sharing. The findings of this study conducted in Heyuan ethnic tourism are not intended to be generalised to all ethnic tourism in China or beyond the case sites. However, the key findings, concepts and ideas presented in case studies may be used to inform both future research and the management of similar ethic tourism development projects. 


\section{REFERENCES}

Abascal, T., Fluker, M., \& Jiang, M. (2016). Domestic demand for indigenous tourism in Australia: Understanding intention to participate. Journal of Sustainable Tourism, 24(8-9), 1350-1368. doi:10.1080/09669582.2016.1193187

Abrahams, R. (2015). Tourism and the reconfiguration of host group identities: A case study of ethnic tourism in rural Guangxi, China. Journal of Tourism and Cultural Change, 13(1), 39-55. doi:10.1080/14766825.2014.892505

Akama, J. S. (1997). Tourism development in Kenya: Problems and policy alternatives. Progress in Tourism and Hospitality Research, 3(3), 95-105.

An, Y. (2006). Discussion on ethnic cultural preservation and the sustainable development of ethnic cultural tourism. Heilongjiang National Series, 92(3), 94-97.

Arnstein, S. R. (1971). Eight rungs on the ladder of citizen participation. In E. S. Cahn \& B. A. Passett (Eds.), Citizen Participation: Effecting Community Change (pp. 69-91). New York: Praeger Publishers.

Aronsson, L. (2000). The Development of Sustainable Tourism. London: Continuum.

Boissevain, J. (1996). Ritual, tourism and cultural commoditization in Malta: Culture by the pound? . In T. Selwyn (Ed.), The Tourist Image: Myth and Myth Making in Tourism (pp. 105-120). Chichester: John Wiley.

Bramwell, B., \& Lane, B. (2010). Sustainable tourism and the evolving roles of government planning. Journal of Sustainable Tourism, 18(1), 1-5.

Bramwell, L., \& Lane, B. (1993). Sustainable tourism: An evolving global approach. Journal of Sustainable Tourism, 1(1), 6- 16.

Britton, S. (1982). The political economy of tourism in the third world. Annals of Tourism Research, 9(3), 331-358.

Bryman, A. (2008). Social Research Methods (3rd ed.). New York: Oxford University Press.

Butler, R., \& Hinch, T. (2007). Tourism and Indigenous Peoples: Issues and Implications. Oxford: Butterworth Heinemann.

Chow, C. ( 2005). Cultural diversity and tourism development in Yunnan Province, China. Geography, 90(3), 294-303.

Cohen, E. (1988). Authenticity and commodificaiton in tourism. Annals of Tourism Research, 15(3), 371-386.

Cornet, C. (2002). Ethnicity in China: Reviewing Ethnicity in light of Ethnic Tourism in Southwest China (Master's dissertation). Unpublished masters thesis McGill University.

Crystal, E. (1989). Tourism in Toraja (Sulawesi, Indonesia). In V. J. Smith (Ed.), Hostsand Guests: The Anthropology of Tourism (pp. 139-168). Philadelphia: University of Pennsylvania Press.

Dongyuan County People's Government. (2014). A government work report in 2014. Retrieved from http://www.gddongyuan.gov.cn/do/bencandy.php?fid=95\&id=5808

Dongyuan County People's Government. (2015). A government work report in 2015. Retrieved 
http://www.gddongyuan.gov.cn/bencandy.php?fid=95\&id=7008

Dwyer, L., Edwards, D., Mistilis, N., Roman, C., \& Scott, N. (2009). Destination and enterprise management for a tourism future. Tourism Management, 30(1)(63-74). doi:10.1016/j.tourman.2008.04.002

Feng, X. H. (2008). Who benefits: Tourism development in Fenghuang County, China. Human Organization, 67(2), 207-229.

Goering, P. G. (1990). The response to tourism in Ladakh. Cultural Survival Quarterly, 14(1), 20-25.

Gossling, S., Ring, A., Dwyer, L., Andersson, A.-C., \& Hall, C. M. (2016). Optimizing or maximizing growth? A challenge for sustainable tourism. Journal of Sustainable Tourism, 24(4), 527-548.

Greenwood, D. J. (1989). Culture By the Pound: An anthropological perspective on tourism as cultural commoditization. In V. J. Smith (Ed.), Host and Guests: The Anthropology of Tourism (pp. 171-185). Philadelphia: University of Pennsylvania Press.

Grünewald, R. d. A. (2003). Tourism and ethnicity. Horizontes Antropológicos, 9(20), 141-159.

Guangdong Statistical Bureau, \& Guangdong Survey Team of National Statistical Bureau. (2013). Statistics communiqué of national economy and social development in Guangdong in 2012. Retrieved from http://www.da.gd.gov.cn/webwww/nychq/NeiRong.aspx?ID=10990

Hall, M. (2007). Politics, power and indigenous tourism. In R. Butler \& T. Hinch (Eds.), Tourism and Indigenous Peoples: Issues and Implications. Burlington, USA: Elsevier Ltd.

Harron, S., \& Weiler, B. (1992). Review: Ethnic tourism. In B.Weiler. \& C. M. Hall (Eds.), Special Interest Tourism (pp. 83-92). London: Belhaven.

Henderson, J. (2003). The politics of tourism on Myanmar. Current Issues in Tourism, 6(2), 97-118.

Heyuan Municipal People's Government. (2013). A government work report in 2013. Retrieved from http:/www.heyuan.gov.cn/web/005/2016060154587-1.shtml

Heyuan Stastics Information Network. (2016a). Heyuan national economic and social development statistical bulletin 2015. Retrieved from http://stats.heyuan.gov.cn/tjzl_8356/tjgb/201604/t20160415_326495.html

Heyuan Stastics Information Network. (2016b). Main indicators of tourism. Retrieved from http://stats.heyuan.gov.cn/tjsj_7971/tjnj/6016nj/10159wjly/201703/t20170322 359188.html

Hitchcock, M. (1999). Tourism and ethnicity: Situational perspectives. International Journal of Tourism Research, 1(1), 17-32.

Huang, S. S., Ryan, C., \& Yang, C. (2013). Local government's roles in developing tourism. In C. Ryan \& S. S. Huang (Eds.), Tourism in China (pp. 190-207). Bristol: Channel View Publications.

Hughes, H. (1994). Tourism and government: A subset of leisure policy? In S. A (Ed.), 
Tourism: The State of the Art (pp. 472-480). Chichester: Wiley.

Ishii, K. (2012). The impact of ethnic tourism on hill tribes in Thailand. Annals of Tourism Research, 39(1), 290-310.

Jamison, D. (1999). Tourism and ethnicity: The brotherhood of coconuts. Annals of Tourism Research, 26(4), 944-967.

Jim, C. Y. (2000). Environmental changes associated with mass urban tourism and nature tourism development in Hong Kong. Environmentalist, 20(3), 233-247.

Li, J. (2004a). Molding Dai-ness on China's Periphery: Ethnic Tourism and the Politics of Identity Construction in Contemporary XishuangBanna (Unpulbished $\mathrm{PhD}$ thesis). Retrieved from repository.upenn.edu.

Li, P., Wang, Q. N., \& Ryan, C. (2013). The impacts of tourism on an Anhui village: The second stage of a Longitudinal study of Mount Qiqun. In C. Ryan \& S. S. Huang (Eds.), Tourism in China (pp. 55-73). Bristol: Channel View publications.

Li, Y. (2000). Ethnic tourism: A Canadian experience. Annals of Tourism Research, 27(1), 115-131.

Li, Y., \& Hinch, T. (1997). Ethnic tourism attractions and their prospect for sustainable development at two sites in China and Canada. Asia Pacific Journal of Tourism Research, 2(1), 5-18.

Liu, H. (2002). Protection of ethnic culture and the sustainable development of ethnic tourism in western area of China. Qinghai Social Science, 1, 47-51. doi : 10.14154/j.cnki.qss.2002.01.011

Luo, Y. (2006). Culture and self-Identity: Overseas Hakka Chinese's awareness of root exploration. Journal of Southwest Ethnic University, 2, 191-195.

Ma, X. J. (2000). On developing national tourism in the western regions and the preservation of national culture. Tourism Tribune, 15(5), 46-49.

Mowforth, M., \& Munt, I. (1998). Tourism and Sustainability: New Tourism in the Third World. London: Routledge.

Mowforth, M., \& Munt, I. (2003). Tourism and Sustainability: Development, Globalisation and New Tourism in the Third World. London: Routledge.

Oakes, T. (1992). Cultural geography and Chinese ethnic tourism. Journal of Cultural Geography, 12(2), 2-17.

Oakes, T. (1998). Tourism and Modernity in China. London: Routledge.

Owen, R. E., Witt, S. F., \& Gammon, S. (1993). Sustainable tourism development in Wales: From theory to practice Tourism Management, 14(6), 463-474.

Park, D., \& Yoon, Y. (2009). Segmentation by motivation in rural tourism: A Korean case study. Tourism Management, 30(1), 99-108. doi : 10.1016/j.tourman.2008.03.011

People's Government of Guangdong Province. (2012). Outline of tourism development plan of Guangdong province (2011-2020). Retrieved from http://zwgk.gd.gov.cn/006939748/201207/t20120712_325776.html

Picard, M., \& Wood, R. (1997). Tourism, Ethnicity, and the State in Asian and Pacific 
Societies. Honolulu: University of Hawaii Press.

Pitchford, S. (1995). Ethnic tourism and nationalism in Wales. Annals of Tourism Research, 22(1), 35-52.

Reimann, M., Lamp, M. L., \& Palang, H. (2011). Tourism impacts and local communities in Estonian National Parks. Scandinavian Journal of Hospitality and Tourism, 11(Suppl. 1), 87-99.

Ruhanen, L. (2013). Local government: Facilitator or inhibitor of susainable tourism development? Journal of Sustainable Tourism, 21(1), 80-98.

Ryan, C., \& Aicken, M. (2005). Indigenous Tourism: The Commodification and Management of Culture. Amsterdam: Elsevier.

Ryan, C., \& Gu, H. (2009). Tourism in China: Destinations, Cultures and Communities. New York Routledge.

Ryan, C., Gu, H., \& Zhang, W. (2009). The context of Chinese tourism: An overview and implications for research. In C. Ryan \& H. Gu (Eds.), Tourism in China: Destination, Cultures and Communities (pp. 327-336). New York: Routledge.

Selwyn, T. (1996). The Tourist Image: Myths and Myth Making in T ourism. Chichester: Wiley.

Shi, B. L., \& Zhao, W. (2006). Idea on national tourism development and national culture protection. Resource Development and Market, 22(5), 489-490.

Smith, S. (1990). Dictionary of Concepts in Recreation and Leasure studies. Westport, CT: Greenwood Publishing Group, Inc.

Smith, V. L. (1989). Hosts and Guests: The Anthropology of Tourism. Philadelphia: University of Pennsylvania Press.

Smith, V. L. (2001). Power and ethnicity in "Paradise": Boracay, Philippines. In V. L. Smith \& M. Brent (Eds.), Hosts and Guests Revisited: Tourism Issues of the 21st Century (pp. 141-152). New York: Cognizant Communication Corp.

Sofield, T., \& Li, F. (1998). Tourism development and cultural policies in China. Annals of Tourism Research, 25(2), 362-392.

Sofield, T. H. B., \& Li, F. M. S. (2007). Indigenous minorities of China and effects of tourism. In R. Butler \& T. Hinch (Eds.), Tourism and Indigenous Peoples: Issues and Implications (pp. 265-280). Oxford : Butterworth-Heinemann.

Stabler, M. J. (1997). Tourism \& Sustainability: Principles to Practice. New York: Cab International.

Swain, M. (1989). Developing ethnic tourism in Yunnan, China: Shilin Sani. Tourism Recreation Research, 14(1), 33-39.

Swarbrooke, J. (1999). Sustainable Tourism Management. Oxon, UK: CABI Publishing.

Taylor, G. (1995). The community approach: Does it really work? Tourism Management, 16(7), 487-489.

Tellis, W. (1997). Application of a case study methodology. Qualitative Report, 3(3), 26-30.

The southern news. (2017). 2016 Guangdong total tourism revenue for US\$19 billion in 2016.

Retrieved from 
http://epaper.southcn.com/nfdaily/html/2017-01/17/content_7613838.htm

Tosun, C. (2000). Limits to community participation in the tourism development process in developing countries. Tourism Management, 21(6), 613-633. doi : 10.1016/S0261-5177(00)00009-1

United Nations. (2005). 2005 world summit outcome. Paper presented at the UNG Assembly, New York.

United Nations World Tourism Organization. (2002). Tourism 2020. Paper presented at the Vision Global Forecasts and Profiles of Market Segments, Madrid.

Urry, J. ( 2002). The Tourist Gaze. London: Sage Publications

van den Berghe, P. (1992). Tourism and the ethnic division of labor. Annals of Tourism Research, 19(2), 234-249.

Van den Berghe, P. (1994). The quest for the other: Ethnic tourism in San Cristobal, Mexico. Seattle: University of Washington Press.

van den Berghe, P., \& Keyes, C. (1984). Introduction tourism and re-created ethnicity. Annals of Tourism Research, 11(3), 343-352. doi: 10.1016/0160-7383(84)90026-4

Wagner, L. M. (2000). The sustainable development imperative and the travel and tourism industry. Retrieved from www.globalpublicpolicy.net

Wang, C., \& Xu, H. (2014). The role of local government and the private sector in China's tourism industry. Tourism Management, 45(12), 95-105. doi : 10.1016/j.tourman.2014.03.008

Wang, D., \& Ap, J. (2013). Tourism policy implementation at the local level in China: A case study of Lijiang. In C. Ryan \& S. S. Huang (Eds.), Tourism in China. Bristol: Channel View Publications.

Whitford, M., \& Ruhanen, L. (2016). Indigenous tourism research, past and present: where to from here? Journal of Sustainable Tourism, 24(8-9), 1080-1099. doi: 10.1080/09669582.2016.1189925

Wood, R. E. (1984). Ethnic tourism, the state, and cultural change in Southeast Asia. Annals of Tourism Research, 11(3), 353-374.

Wood, R. E.(1993). Tourism, culture and the sociology of development. In M. Hitchcock, V. T. King, \& M. Parnwell (Eds.), Tourism in Southeast Asia (pp. 48-70). London: Routledge.

Wood, R. E. (1997). Tourism and the state: Ethnic options and construction of otherness. In M. Picard \& R. E. Wood (Eds.), Tourism, Ethnicity and the State in Asian and Pacific Societies (pp. 1-34). Honolulu: University of Hawaii Press.

World Commission on Environment and Development. (1987). Our Common Future. Oxford: Oxford University Press.

Xie, P. (2001). Authenticating Cultural Tourism: Folk Villages in Hainan, unpublished PhD thesis, University of Waterloo.

Xie, P., Wall, G. (2002). Visitors' perceptions of authenticity at cultural attractions in Hainan, China. International Journal of Tourism Research, 4(5),353-366. 
Xu, H., \& Sofield, T. (2013). Sustainability in Chinese development tourism policies. Current Issues in Tourism. doi:10.1080/13683500.2013.849665

xzqhnet. (2009). Administrative divisions of Heyuan of 2008. Retrieved from http://www.xzqh.org/html/show/gd/16243.html

Yang, J., Ryan, C., \& Zhang, L. (2013). Social conflict in communities impacted by tourism. Tourism Management, 35(2), 82-93.

Yang, J., Ryan, C., \& Zhang, L. (2014). Sustaining culture and seeking a Just Destination: governments, power and tension-a life-cycle approach to analysing tourism development in an ethnic-inhabited scenic area in Xinjiang, China. Journal of Sustainable Tourism, 22(8), 1151-1174.

Yang, L. (2011). Ethnic tourism and cultural representation. Annals of Tourism Research, 38(2), 561-585. doi:10.1016/j.annals.2010.10.009

Yang, L. (2012). Tourist's perceptions of ethnic tourism in Lugu Lake, Yunnan, China. Annals of Tourism Research, 38(2), 561-585.

Yang, L. (2013). Ethnic tourism and minority identity: Lugu Lake, Yunnan, China. Asia Pacific Journal of Tourism Research, 18(7), 712-730. doi: 10.1080/10941665.2012.695289

Yang, L., \& Wall, G. (2009). Ethnic tourism: A framework and an application. Tourism Management, 30(4), 559-570.

Yang, L., Wall, G., \& Smith, S. L. J. (2008). Ethnic tourism development: Chinese government perspectives. Annals of Tourism Research, 35(3), 751-771. doi:10.1016/j.annals.2008.06.005

Ye, W., \& Xue, X. (2008). The differences in ecotourism between China and the West. Current Issues in Tourism, 11(6), 567-586. doi: 10.1080/13683500802475927

Ying, T., \& Zhou, Y. (2007). Community, governments and external capitals in China's rural cultural tourism: A comparative study of two adjacent villages. Tourism Management, 28(1), 96-107. doi:10.1016/j.tourman.2005.12.025

Zhang, H. Q., Fan, D. X. F., Tse, T. S. M., \& King, B. (2016). Creating a scale for assessing socially sustainable tourism. Journal of Sustainable Tourism. doi:http://www.tandfonline.com/action/showCitFormats?doi=10.1080/096695 82.2016.1173044

Zheng, H., \& Huang, D. (2010, November). Hakka's formation and development. Paper presented at the The 23rd world Hakka membership conference, Heyuan, China.

Zhou, D. (2014). Anthropology and ethnic tourism: Practices in China. Tourism Tribune 29(2), 103-109.

Zolfani, S. H., Maedeh Sedaghat, R. M., \& Zavadskas, E. K. (2015). Sustainable tourism: A comprehensive literature review on frameworks and applications. Economic Research-Ekonomska Istraživanja, 28(1), 1-30. 


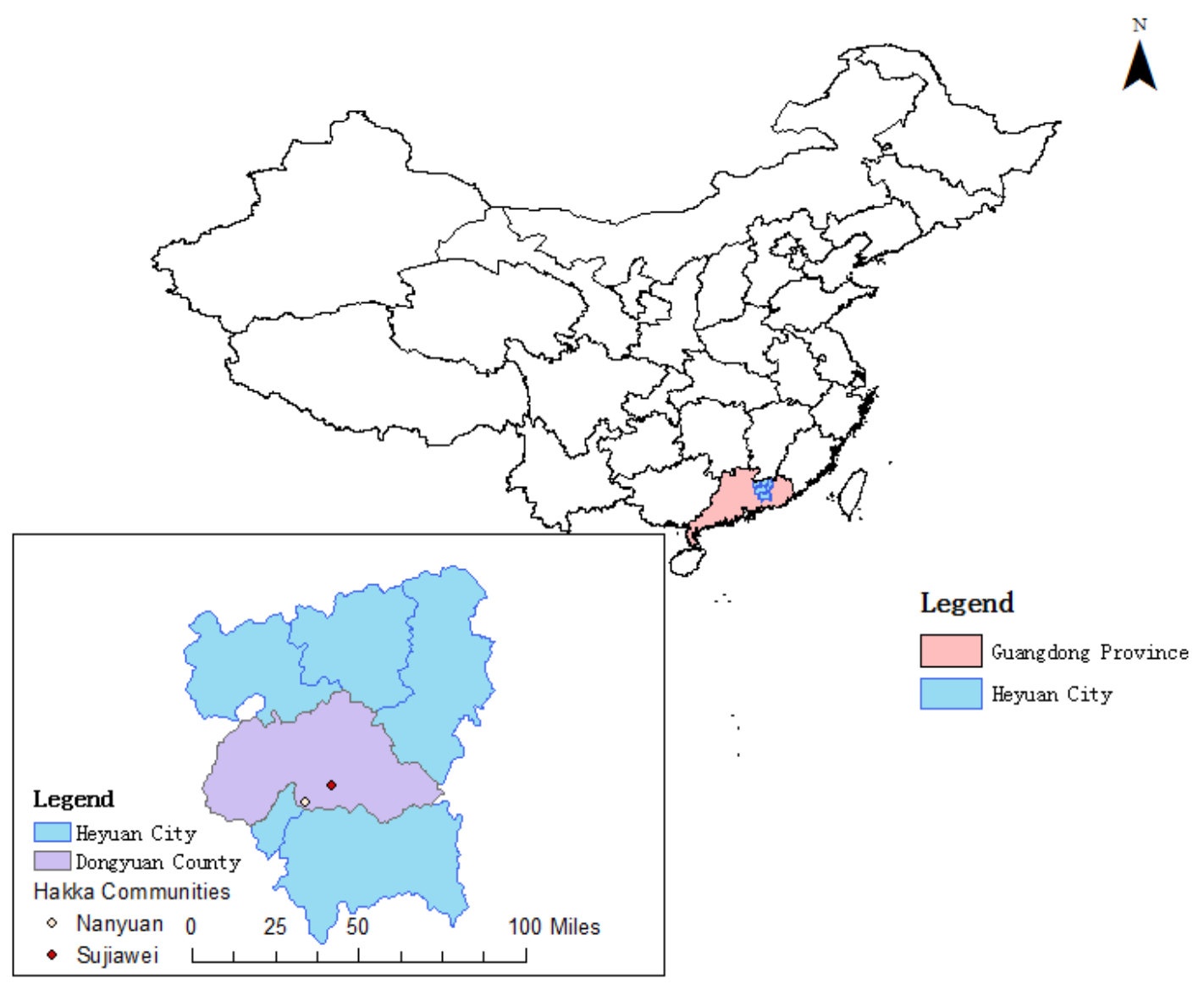

Figure 1: Location of Nanyuan and Sujiawei villages in Heyuan, Guangdong Province, China 
Table 1: The tourism settings of Nanyuan and Sujiawei

\begin{tabular}{|c|c|c|}
\hline & Nanyuan & Sujiawei \\
\hline History & $\begin{array}{l}\text { Built in } 1585 \mathrm{AD}, \text { a } \\
\text { history of about } 432 \text { years }\end{array}$ & $\begin{array}{l}\text { A history of over } 700 \\
\text { years }\end{array}$ \\
\hline Population & $\begin{array}{l}\text { About } 500 \text { households, } \\
\text { about } 2000 \text { local Hakkas }\end{array}$ & $\begin{array}{l}\text { About } 40 \text { households, over } \\
200 \text { local Hakkas }\end{array}$ \\
\hline Area & 1260 hectares, & 373 hectares \\
\hline Administrative affiliation & $\begin{array}{l}\text { Under Xiantang Town, } \\
\text { Dongyuan County }\end{array}$ & $\begin{array}{l}\text { Under Yihe Town, } \\
\text { Dongyuan County }\end{array}$ \\
\hline Origin of tourism & 2004 & 2001 \\
\hline Renown and honours & $\begin{array}{l}\text { A shooting location for } \mathrm{TV} \\
\text { programs or movies } \\
\text { Ancient Hakka village of } \\
\text { South China }\end{array}$ & $\begin{array}{l}\text { "National Agricultural } \\
\text { Tourism Model" } \\
\text { Model of Poverty } \\
\text { Alleviation by Tourism in } \\
\text { Guangdong Province } \\
\text { the "Most Beautiful } \\
\text { Village of Guangdong } \\
\text { Province" } \\
\text { "Distinctive } \\
\text { Village of Guangdong } \\
\text { Province" }\end{array}$ \\
\hline $\begin{array}{l}\text { Social structure and } \\
\text { culture }\end{array}$ & \multicolumn{2}{|c|}{$\begin{array}{l}\text { - Clan as the base of the community's social structure } \\
\text { - The representations of Hakka Culture in South China } \\
\text { - A single family name is shared in the community, with } \\
\text { 'Pan' in Nanyuan and 'Su' in Sujiawei }\end{array}$} \\
\hline Tourist attractions & \multicolumn{2}{|c|}{$\begin{array}{l}\text {-Hakka historic buildings } \\
\text {-Traditional Hakka culture and customs } \\
\text {-A "Countryside Tour" }\end{array}$} \\
\hline
\end{tabular}


Table 2: Socially Sustainable Ethnic Tourism Themes

\begin{tabular}{|c|c|c|}
\hline $\begin{array}{l}\text { Overarching } \\
\text { theme }\end{array}$ & Main themes & Sub-themes \\
\hline \multirow{9}{*}{$\begin{array}{l}\text { Socially } \\
\text { Sustainable } \\
\text { Ethnic } \\
\text { Tourism }\end{array}$} & \multirow[t]{2}{*}{ Social sustainability } & $\begin{array}{l}\text { Quality of life in the host community (control } \\
\text { over development; equity of access to benefits; } \\
\text { social harmony) }\end{array}$ \\
\hline & & $\begin{array}{l}\text { Quality of ethnic tourism experience } \\
\text { (conservation; authenticity; diversity) }\end{array}$ \\
\hline & \multirow{2}{*}{$\begin{array}{l}\text { Community } \\
\text { participation and } \\
\text { perceptions }\end{array}$} & Perceptions of satisfaction and involvement \\
\hline & & $\begin{array}{l}\text { Involvement in decision-making; provisions for } \\
\text { community consultation; tourism management; } \\
\text { tourism operations; distribution of benefits }\end{array}$ \\
\hline & \multirow[t]{2}{*}{$\begin{array}{l}\text { The role of local } \\
\text { government }\end{array}$} & $\begin{array}{l}\text { Level/type of government involvement and } \\
\text { influence }\end{array}$ \\
\hline & & $\begin{array}{l}\text { Mechanisms of government involvement } \\
\text { (planning; regulation; business operation; } \\
\text { stimulation; tourism promotion; education; } \\
\text { coordination) }\end{array}$ \\
\hline & \multirow[t]{3}{*}{$\begin{array}{l}\text { Sustainable interest } \\
\text { group relationships }\end{array}$} & $\begin{array}{l}\text { Public sector policies (planning \& consultation; } \\
\text { legislation/regulations; co-ordination) }\end{array}$ \\
\hline & & $\begin{array}{l}\text { Policy/planning implementation (resources; } \\
\text { capacity building) }\end{array}$ \\
\hline & & $\begin{array}{l}\text { Partnership building (needs \& interests; } \\
\text { communication) }\end{array}$ \\
\hline
\end{tabular}


Table 3: Social sustainability in ethnic tourism in Nanyuan and Sujiawei

\begin{tabular}{|c|c|c|}
\hline Characteristics & Nanyuan & Sujiawei \\
\hline $\begin{array}{l}\text { Quality of life } \\
\text { Local control } \\
\text { Local benefits }\end{array}$ & 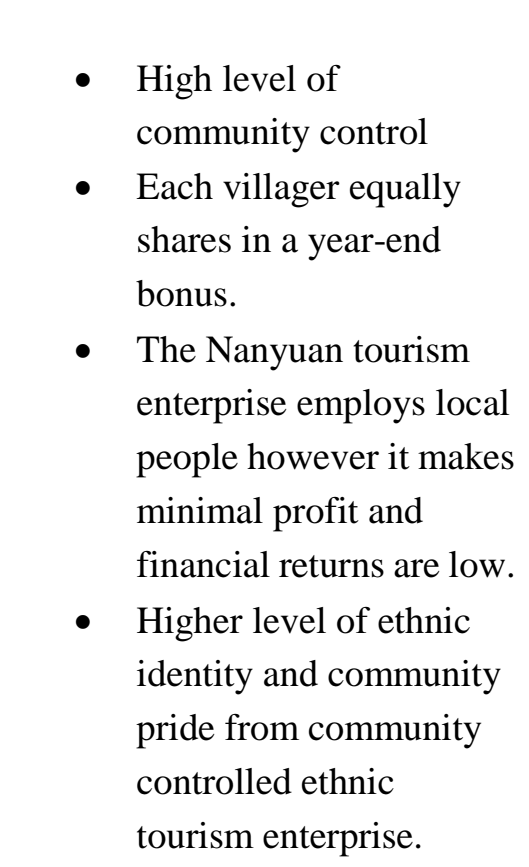 & $\begin{array}{l}\text { - External management, minimal } \\
\text { community input into } \\
\text { management decisions } \\
\text { - The local community gains a } \\
\text { small portion of the profits. } \\
\text { - The Sujiawei tourism } \\
\text { enterprise has created many } \\
\text { jobs and business opportunities } \\
\text { for local residents and has } \\
\text { contributed to a significant } \\
\text { growth of household income. } \\
\text { Environmental enhancement of } \\
\text { Sujiawei and an enhanced } \\
\text { sense of Hakka ethnic identity }\end{array}$ \\
\hline $\begin{array}{l}\text { Local } \\
\text { community } \\
\text { participations } \\
\text { and perceptions } \\
\end{array}$ & $\begin{array}{l}\text { - } 54 \% \text { local satisfaction } \\
\text { with ethnic tourism } \\
\text { development (household } \\
\text { study) }\end{array}$ & $\begin{array}{l}\text { - } 23 \% \text { local satisfaction with } \\
\text { ethnic tourism development } \\
\text { (household study) }\end{array}$ \\
\hline Authenticity & $\begin{array}{l}\text { - } \text { The tourism experience } \\
\text { limited to visual } \\
\text { upgrading of historic } \\
\text { buildings and ad hoc } \\
\text { retailing. The ethnic } \\
\text { village heavily } \\
\text { infiltrated } \\
\text { surrounded } \\
\text { modernity. } \\
\text { - } \\
\text { Unrated by Tourism } \\
\text { authorities }\end{array}$ & $\begin{array}{l}\text { - The historic village retained a } \\
\text { high level of historic } \\
\text { authenticity. } \\
\text { - Many activities and } \\
\text { opportunities for interactive } \\
\text { engagement between tourists } \\
\text { and Hakka community. }\end{array}$ \\
\hline
\end{tabular}

